\title{
Position and Role of School-enterprise Cooperation in Construction of Higher Vocational Schools' Practical Teaching System
}

\author{
Shujing Liu ${ }^{1}$, Chungang Niu ${ }^{1}$ \\ ${ }^{1}$ Hebei Jiaotong Vocational and Technical College, Shijiazhuang, 050035, China
}

Key words: School-enterprise cooperation; High vocational schools; Practical teaching system

\begin{abstract}
Indeed, competition among enterprises in modern society lies on competition about talent quality. Improving core competitiveness of enterprise talent not only acts as one of the important ways to realize school-enterprise cooperation in high vocational schools' practical teaching but also is a basic approach by which enterprises can realize sustainable development. Thus, it can be said that school-enterprise cooperation is one of the significant methods for high vocational schools' practical teaching. Based on analyzing meaning of school-enterprise cooperation, this thesis elaborates the position and role that school-enterprise cooperation plays in construction of high vocational schools’ practical teaching system.
\end{abstract}

\section{Connotation of school-enterprise cooperation}

After Chinese higher vocational education has developed for over 20 years, school-enterprise cooperation and practical teaching have obtained favorable development, which is sufficiently reflected by the situation that the important role that practical teaching plays in improving higher vocational students' comprehensive quality is approved gradually. This proposes new and higher requirements for practical teaching of higher vocational schools. For this, higher vocational schools should devote themselves to cultivating higher vocational students' practical skills and ability as well as improve their working skills and comprehensive quality on the basis that basic theoretical knowledge teaching is strengthened. Besides, schools should rely on the training base jointly built by school-enterprise cooperation to construct a good platform for practical teaching, combine theory with practice, and lay particular emphasis on comprehensive cultivation of higher vocational students' professional and theoretical knowledge and practical ability. The said school-enterprise cooperation is mainly one of the educational modes, which involves that higher vocational schools sign agreements with employers, realize mutual cooperation, make and carry out cultivation schemes about higher vocational talent via complementary advantages and cultivate talented people with high quality and high skills, who are needed by enterprises urgently. It is called cooperative education in foreign vocational education world. School-enterprise cooperation is a teaching form, which can exert advantages of higher vocational schools and enterprises, use different kinds of educational training environment and sites to combine campus learning with trainings at regular posts of enterprises effectively, let students apply theoretical knowledge and skills to specific work and bring problems that appear in practical training to schools to implement re-cultivation in order to promote comprehensive unification of teaching, learning and doing.

\section{Position of school-enterprise cooperation in construction of higher vocational schools' practical teaching system}

Up to now, higher vocational education of China has entered an era of popular style. Besides, the phenomenon that supply of total labor force of China will exceed demands will appear within a period in future. As a result, employment of college students including higher vocational students will face with increasingly severe challenges inevitably. Thus, employment difficulty has become an indisputable fact. The reason for employment difficulty of higher vocational students not only involves the economic environment where they stay and demands of employers in the market but also lies in that the degree to which schools give guidance service during their school life is not deep enough. Thus, they commonly face with a crisis in the aspect of employability. Practical teaching is a complete process in which theoretical knowledge and practical skills, i.e., indirect 
knowledge and direct experience, are combined. Generally speaking, practical teaching can be divided into two parts, i.e., practical training inside schools and practical training outside schools. The former trains higher vocational students' observation, thinking and practical ability purposefully with pertinence according to content and schedule of theoretical teaching, while the latter is implemented via mutual cooperation between higher vocational schools and enterprises. The position of school-enterprise cooperation in higher vocational schools' practical teaching system is shown as follows:

Firstly, it can improve higher vocational teaching quality and higher vocational students' practical ability. School-enterprise cooperation is based on mutual communication between schools and enterprises and helps higher vocational students to combine knowledge they have learned from books with enterprises' production reality in practice in order to realize comprehensive mastery and study. When higher vocational students take part in practical learning at enterprises, they not only aim at obtaining needed credits and finishing corresponding courses but learn the enterprise's processes like production and operation by this so that they can master how the major they learn exerts its effect at enterprises and make solid mental and action preparation for their future employment.

Secondly, it can improve teachers' quality. By virtue of the carrier school-enterprise cooperation, higher vocational schools may invite cooperative enterprise experts or professional technicians to give lessons and introduce the latest development situations of the industry as well as practical application effect of new technology and new process. At the same time, schools need invite some enterprise experts and technicians to be part-time teachers and build a group of guest and part-time teachers. In doing so, the problem that teachers are not enough can be solved and shortages of higher vocational schools' professional teachers in the aspect of practical knowledge can be remedied. Via practical learning at enterprises, higher vocational students can combine the theoretical knowledge that they have learned with enterprises' production practice to finish the change from theoretical study to practical application. Meanwhile, they can use the enterprise's demands and solved specific problems as research topics of their graduation projects or theses. By joint guidance of schools' teachers and enterprise experts, students can finish these research topics that combine theory with practice as much as possible and apply them to production practice.

Thirdly, it can cultivate professional talent that adapts to demands of talent market. Based on development of school-enterprise cooperation, higher vocational schools may propose differentiated demands according to the market and cultivate talented people that the society needs urgently according to local circumstances. Higher vocational schools mainly cultivate skilled talent with professional skills, so it is essential to cultivate needed talent according to demands of the current society in order to avoid disjunction between demand and supply.

Fourthly, it can expand teaching resources actively. Since all industries develop rapidly, content of the teaching materials used by practical teaching of higher vocational schools appears to be old. After implementing school-enterprise cooperation, it is completely possible to go to the front line of production to do exploration, learn the latest trend and development tendency of major development, master current market demands better, obtain the latest materials from enterprises' production and operation, use them as the latest content of practical teaching development and make new teaching materials adapt to practical demands to a larger extent by joint cooperation between professional teachers at higher vocational schools and enterprises’ professional technicians.

\section{Role of school-enterprise cooperation in construction of higher vocational schools' practical teaching system}

\subsection{Realizing standardization of higher vocational colleges' operating mechanism}

School-enterprise cooperation can be driven to develop towards a healthy and standard direction and better social value can be achieved only when a set of normalized long-acting operating mechanisms are established practically. On the one hand, from the perspective of microcosmic perspective, both schools and enterprises should apply systematic opinions to give comprehensive consideration and implement various work about school-enterprise cooperation, for instance, 
establishing a new system, in order to provide good guarantee for successful implementation of school-enterprise cooperation. Higher vocational schools should not only formulate regulations and systems that accord with their own situations, such as development planning about school-enterprise cooperation and provisions related to higher vocational students' post practice, but also establish offices for university-industry cooperation and ask full-time workers to be responsible for implementing operating work of school-enterprise cooperation and build professional building mechanism that experts of cooperative enterprises take part in to make both parties of school-enterprise cooperation communicate with each other frequently and guarantee both parties' demands for benefits better. Besides, they should construct a more long-term and new educational system for cooperation. In doing so, problems, for example, the friction between existing system of schools and enterprises' operating system, can be solved to ensure smooth operation. On the other hand, from the perspective of macroscopic system, active exertion of prominent roles mainly lies in the country and governments at all levels. Government sectors should use specific actions to implement their attention to school-enterprise cooperation, strengthen and perfect operating mechanism of school-enterprise cooperation and drive school-enterprise cooperation to cover a road of standardization and institutionalization development practically. Therefore, it is essential to strengthen and perfect all kinds of system actively, make policies related to school-enterprise cooperation according to local circumstances and work out reasonable management measures to make school-enterprise cooperation have laws to abide by. At the same time, we should strengthen and perfect reward system of school-enterprise cooperation energetically, commend and reward enterprises that make many achievements in the process of school-enterprise cooperation and give much priority to them in the aspect of tax and credit to improve subjective initiative of enterprises' participation in cooperation. Moreover, it is necessary to enlarge construction force, establish specialized organizations at national, provincial and municipal levels, for instance, school-enterprise cooperation associations, and draw up more authoritative and more complete instruction manual for school-enterprise cooperation in order to improve standardization and scientization degree of the work. Facts have proved that the working mechanism that governments 'build stages' and schools and enterprises 'perform in opera' is quite successful. Whether the opera can be played well or not, the role of the government behind the scene appears to be very important. A long-term, cooperative and good situation can be created for the cooperation between schools and enterprises and school-enterprise cooperation can succeed only when the government strengthens and perfects macroscopic operating system.

3.2 Realizing mutual benefits and win-win results of higher vocational schools and enterprises

As a cooperative form with strong complementarity, school-enterprise cooperation is supported by schools and enterprises. Via bi-directional intervention and resource sharing, it becomes an important way to realize sustainable development in education and production. However, enterprises and higher vocational schools are two different interest subjects. The school-enterprise cooperation without common interests lacks enough vitality and cooperation cannot be implemented for a long time. In the process of school-enterprise cooperation, both schools and enterprises should learn transpositonal consideration, i.e., they can think about problems from the other's perspective. Higher vocational schools should strengthen service for cooperative enterprises, use service to obtain support to the largest extent, apply contribution to promote the cooperation between them, go to cooperative enterprises actively to learn their situations and features in the aspects of production, operation, management and enterprise culture, and understand demands proposed by enterprises in the aspects of product research, technological innovation, brand establishment, cultural construction and human resources of enterprise more actively. Besides, schools ought to provide enough support and service for various demands of enterprises according to their features and requirements and promote the enterprise's brand on the basis that high-quality vocational educational brand is established. Based on providing support in the aspects of graduate student resources, teachers and talent actively, higher vocational schools should also devote themselves to exerting their advantages in scientific researches, help all cooperative enterprises with technical reform and upgrading, assist enterprises in promoting reform and enhance their own 
development. Enterprises should also help higher vocational schools more actively to cultivate an increasing number of higher vocational talented people and provide energetic support in all aspects like school-running funds and equipment to drive cooperative school vigorously to realize better development. The vitality of school-enterprise cooperation lies in realization of a win-win situation. Both schools and enterprises can reach consensus, form a benefit community, realize sharing of polices, resources and achievements and generate a circulating system that can realize sustainable development only when they find out the joint point of interests accurately.

\subsection{Realizing integration of higher vocational culture and enterprise culture}

Higher vocational campus culture and enterprises culture are two completely different ones. Implication of higher vocational campus culture that it aims at educating people, and it mainly advocates scientific spirit, while enterprise culture means 'quality' and advocates entrepreneurship and spirit of innovation. Via school-enterprise cooperation, collision and connection between two different cultures of schools and enterprises can be realized well. When schools cooperate with enterprises, teachers' and students are also employees of enterprises and enterprises' employees may be part-time teachers as well. Implementation of school-enterprise cooperation is helpful for higher vocational schools to absorb advanced work ideas at modern enterprises and serve schools' management. Higher vocational students learn professional theoretical knowledge and go to the front line of cooperative enterprises to practice their work based on this. Thus, higher vocational students' responsibility and initiative can be improved largely with encouragement of enterprise culture and spirit. Besides, improvement in all kinds of occupational qualities like innovation ability, interpersonal skill and team spirit can be accelerated. Integration of cultural essence, such as professional ethics and team spirit of cooperative enterprises' employees, into schools' campus culture is quite helpful for schools to build the goal that they direct at cultivating excellent skilled talent and reflect more distinct school-running features of higher vocational schools. At the same time, school-enterprise cooperation can help enterprises build more advanced enterprises culture and make enterprises realize better development. Numerous higher vocational teachers and students apply close connection between both parties of school-enterprise cooperation in the process of enterprises' practice and training, which can integrate rigorous, realistic and enterprising spirit of higher vocational schools into enterprises so that higher vocational campus culture can affect enterprises unconsciously. Meanwhile, advantages of higher vocational human resources can provide more active support for cultural transmission of enterprises. A whole with more specific functions can be formed and optimal benefits of school-enterprise cooperation can be realized practically only when huge advantages of school-enterprise cooperation such a platform is exerted to a larger extent and both parties of school-enterprise cooperation learn and imitate each other's advantages.

\section{Conclusion}

To sump up, for construction and development of our higher vocational colleges' practical teaching system, it is essential to focus on school-enterprise cooperation, promote a closer cooperative relation to be established between schools and enterprises and construct high-quality practical teaching base. This not only acts as an inevitable choice of social development at present but also serves as an important way to accelerate our industrial innovation and a good approach to solve high vocational students' employment difficulty. Higher vocational schools will explore a school-enterprise cooperation and development road with distinct higher vocational features as long as they continue strengthening and perfecting practical teaching mode of school-enterprise cooperation, carry out innovation boldly and combine practical situations of higher vocational schools to perform implementation.

\section{Acknowledgments}

This thesis is a project of higher educational reform in Hebei province in 2012 (project No.: 2012GJJG187) and the project that was funded intensively in college-level higher educational 
reform of Hebei Jiaotong Vocational \& technical College (project No.: 2011002). The task name is Research on Higher Vocational Schools' Practical Teaching System Construction of Majors Related to Transportation.

\section{References}

[1] Li Hongwei and Feng Lei. Research on the Quality Monitoring and Evaluation System for the School-enterprise Cooperation Talent Training Mode [J]. Electronics Technology, 2010(6).

[2] Chen Weiping. Exploration on Practical Teaching of Higher Vocational 'Introduction' Course Based on School-enterprise Cooperation [J]. Schools' Party Construction and Ideological Education, 2012(21).

[3] Wang Yan. Thoughts of Practical Teaching in Higher Vocational Education Based on Deeply Cooperation between College and Enterprise [J]. Journal of Zhejiang Vocational and Technical Institute of Transportation, 2013(4).

[4] Qian Zheng. Research on Higher Vocational Capstone Course Teaching Practice Based on School-enterprise Deep Cooperation [J]. Journal of Jiamusi Education Institute, 2014(5). 